2011s-54

\title{
The Study of Compensation Systems Through the Lens of Self-Determination Theory: Reconciling 35 Years of Debate
}

Marylène Gagné, Jacques Forest

Série Scientifique
Scientific Series

Montréal

Août 2011

(C) 2011 Marylène Gagné, Jacquest Forest. Tous droits réservés. All rights reserved. Reproduction partielle permise avec citation du document source, incluant la notice $($.

Short sections may be quoted without explicit permission, if full credit, including (C) notice, is given to the source.
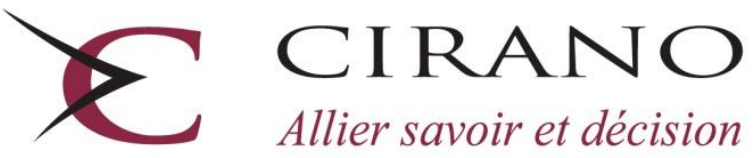

Allier savoir et décision

Centre interuniversitaire de recherche en analyse des organisations 


\section{CIRANO}

Le CIRANO est un organisme sans but lucratif constitué en vertu de la Loi des compagnies du Québec. Le financement de son infrastructure et de ses activités de recherche provient des cotisations de ses organisations-membres, d'une subvention d'infrastructure du Ministère du Développement économique et régional et de la Recherche, de même que des subventions et mandats obtenus par ses équipes de recherche.

CIRANO is a private non-profit organization incorporated under the Québec Companies Act. Its infrastructure and research activities are funded through fees paid by member organizations, an infrastructure grant from the Ministère du Développement économique et régional et de la Recherche, and grants and research mandates obtained by its research teams.

\section{Les partenaires du CIRANO}

\section{Partenaire majeur}

Ministère du Développement économique, de l'Innovation et de l'Exportation

\section{Partenaires corporatifs}

Autorité des marchés financiers

Banque de développement du Canada

Banque du Canada

Banque Laurentienne du Canada

Banque Nationale du Canada

Banque Royale du Canada

Banque Scotia

Bell Canada

BMO Groupe financier

Caisse de dépôt et placement du Québec

\section{CSST}

Fédération des caisses Desjardins du Québec

Financière Sun Life, Québec

Gaz Métro

Hydro-Québec

Industrie Canada

Investissements PSP

Ministère des Finances du Québec

Power Corporation du Canada

Rio Tinto Alcan

State Street Global Advisors

Transat A.T.

Ville de Montréal

\section{Partenaires universitaires}

École Polytechnique de Montréal

HEC Montréal

McGill University

Université Concordia

Université de Montréal

Université de Sherbrooke

Université du Québec

Université du Québec à Montréal

Université Laval

Le CIRANO collabore avec de nombreux centres et chaires de recherche universitaires dont on peut consulter la liste sur son site web.

Les cahiers de la série scientifique (CS) visent à rendre accessibles des résultats de recherche effectuée au CIRANO afin de susciter échanges et commentaires. Ces cahiers sont écrits dans le style des publications scientifiques. Les idées et les opinions émises sont sous l'unique responsabilité des auteurs et ne représentent pas nécessairement les positions du CIRANO ou de ses partenaires.

This paper presents research carried out at CIRANO and aims at encouraging discussion and comment. The observations and viewpoints expressed are the sole responsibility of the authors. They do not necessarily represent positions of CIRANO or its partners. 


\title{
The Study of Compensation Systems Through the Lens of Self-Determination Theory: Reconciling 35 Years of Debate ${ }^{1}$
}

\author{
Marylène Gagné2, Jacques Forest ${ }^{3}$
}

\begin{abstract}
Résumé / Abstract
Si les spécialistes en rémunération sont généralement en faveur des systèmes de primes qui lient la récompense à la performance, la théorie de l'autodétermination, quant à elle, suggère que de telles récompenses contingentes peuvent nuire à la motivation autonome. Nous présentons un modèle des effets motivationnels engendrés par les systèmes de rémunération qui tente de faire concorder la théorie de l'autodétermination avec la documentation sur la rémunération. Ce modèle évalue de quelle façon les caractéristiques des systèmes de rémunération, tels les variations de la rémunération et son niveau, peuvent influer sur la satisfaction du besoin d'autonomie, la compétence et le rapprochement, lesquels peuvent, à leur tour, marquer la motivation autonome au travail.
\end{abstract}

Mots clés : théorie de l'autodétermination, compensation, récompenses, mesures incitatives, justice organisationnelle.

Although compensation specialists generally argue for incentive systems that link rewards to performance, self-determination theory argues that such contingent rewards can have detrimental effects on autonomous motivation. The authors present a model of the motivational effects of compensation systems that attempts to reconcile the self-determination theory view and the literature on compensation. This model evaluates how compensation system characteristics, such as the amount and variability of pay, can influence the satisfaction of the needs for autonomy, competence, and relatedness, which in turn influence autonomous work motivation.

Keywords: self-determination theory, compensation, rewards, incentives, organizational justice.

\footnotetext{
${ }^{1}$ La référence de l'article original publié est la suivante: Gagné, M., \& Forest, J. (2008). The study of compensation systems through the lens of Self-Determination Theory: Reconciling 35 years of debate. Canadian Psychology, 49, 225-232.

We thank Edward Deci, Gary Johns, Richard Koestner, and two anonymous reviewers for their helpful comments on earlier drafts. This work was partially funded by a team grant from the Fonds Québécois de Recherche Sur la Société et la Culture, Quebec (FQRSC) to Marylène Gagné.

${ }^{2}$ École de Gestion John-Molson (Université Concordia).

${ }^{3}$ École des Sciences de la Gestion de l'UQAM, forest.jacques@uqam.ca.
} 
Self-determination theory (SDT; Deci \& Ryan, 1985, 2000) has been used only occasionally to understand organizational behavior,despite the fact that the theory offers tremendous potential to studyorganizational processes and outcomes. We will briefly review organizational research that has been conducted with selfdetermination theory, and identify gaps in our knowledge of organizational behavior that could be filled by using this framework.

We will concentrate especially on the field of compensation. SDT distinguishes between intrinsic motivation and extrinsic motivation. Intrinsic motivation refers to doing an activity for its own sake, because one finds the activity inherently interesting and satisfying. In contrast, extrinsic motivation refers to doing an activity for an instrumental reason. There are different types of extrinsic motivation that can be relatively controlled by external factors, or that can be relatively autonomous, that is, regulated through a person's acquired goals and values. These types of motivation can be aligned along a continuum representing the degree to which they have been internalized. Internalization is defined as "the active assimilation of behavioral regulations that are originally alien or external to the self" (Ryan, 1995, p. 405). At the low-end lies external regulation, which refers to doing an activity solely to obtain rewards or to avoid punishments. Next, introjected regulation refers to the regulation of behavior through self-worth contingencies like ego-involvement and guilt. It involves taking in a regulation so that it becomes internally pressuring, and thus involves only partial internalization that remains controlled, not volitional. Next, identified regulation refers to doing an activity because one identifies with its value or meaning, and accepts it as one's own, which means that it is autonomously regulated. Finally, integrated regulation refers to identifying with the value of an activity to the point that it becomes habitual and part of the person's sense of self. This is the form of extrinsic motivation that is most fully internalized and autonomous. External regulation and introjection are often categorized as controlled motivation whereas identification, integration, and intrinsic motivation represent autonomous motivation.

Autonomous motivation has been associated with active information seeking (Koestner \& Losier, 2002), goal attainment (Sheldon \& Elliot, 1998), better performance (Amabile, Goldfarb, \& Brackfield, 1990; Baard et al., 2004), and increased well-being (Ilardi et al., 1993). Controlled motivation has been associated with inconsistent goal striving (Koestner, Losier, Vallerand, \& Carducci, 1996), vulnerability to persuasion (Koestner \& Losier, 2002), and impaired performance and persistence because of concentration and memory difficulties (see Vallerand, 1997 for a review). Autonomous motivation can be promoted by contexts that satisfy the three basic psychological needs of competence, autonomy and relatedness (Deci \& Ryan, 2000). Therefore, need satisfaction is the key to promoting optimal functioning, including performance improvement and increased well-being. Optimal functioning in work organizations can be translated as employee engagement, performance, well-being, and retention. Organizations strive to attract and keep employees who are competent, fully engaged, and healthy. There is some support for the importance of need satisfaction in work organizations, as it has been related to better performance, engagement, well-being, and retention (Baard et al., 2004; Deci, Gagne', Ryan, Leone, Usunov, \& Kornazheva, 2001; Gagne', 2003; Meyer \& Gagne’, 2008). 
We propose that there are three important organizational levers that influence work-related need satisfaction: job design, interpersonal relations, and compensation. Need satisfaction and autonomous motivation have been associated with jobs that are designed to be more interesting and meaningful (Gagne', Sene'cal, \& Koestner, 1997; Millette \& Gagne', 2008). They have also been linked to managerial support (Baard et al., 2004; Deci et al., 2001; Lynch, Plant, \& Ryan, 2005) and transformational leadership (Bono \& Judge, 2003), which refers to managers being charismatic, inspirational, and considerate toward subordinates. Controlled motivation, on the other hand, has been associated with the presence of contingent rewards (Deci, Koestner, \& Ryan, 1999), deadlines (Amabile, DeJong, \& Lepper, 1976), surveillance (Lepper \& Greene, 1975), and evaluations (Smith, 1975). Controlled motivation appears to be forestalled by transformational leadership (Bono \& Judge, 2003). However, we know of no research that has examined the effects of compensation systems on employee need satisfaction and work autonomous motivation. We will therefore concentrate on analyzing the compensation literature and propose new research avenues in this field. We first describe experimental research on the effects of rewards on motivation.

\section{Rewards and Motivation}

Laboratory studies that have examined the effects of rewards on intrinsic motivation have yielded mixed results and given rise to a heated debate on the effects of rewards on intrinsic motivation. Deci, Koestner, and Ryan (1999) attempted to clarify this debate with a metaanalysis of 128 laboratory studies. Results showed that the net effect of rewards on freechoice behavior (engaging in a task in the absence of external prods) was moderately negative. However, the effect was positive for verbal rewards, and negative for tangible rewards. An important moderator of the link between tangible rewards and intrinsic motivation was the type of contingency. Obtaining a reward simply for engaging in a behavior and obtaining a reward for simply completing a task had greater detrimental effects than obtaining a reward contingent on attaining a specified level of performance (i.e., a performance contingent reward).

These findings can be explained through the impact of rewards on need satisfaction. For example, performance contingent rewards can affect autonomy negatively by changing the rewardee's locus of causality from internal to external (like other kinds of contingent rewards), but they can also positively affect feelings of competence by providing information about behavioral effectiveness. These two simultaneous effects may offset each other in influencing intrinsic motivation. However, three important warnings have been offered regarding the use of performance-contingent rewards (Deci, Koestner, \& Ryan, 2001). First, the precise impact of a performance-contingent reward appears to depend on whether its controlling or competence aspect is made salient by the interpersonal context (Ryan, Mims, \& Koestner, 1983). Second, the use of performance-contingent rewards in real-life contexts will typically require additional controlling features such as surveillance, evaluation, and competition, all of which can negatively impact motivation. Finally, the use of performance contingent rewards in real-life context will often result in many individuals failing to receive the reward because their performance does not meet the required criteria, and there is clear evidence that such outcomes are highly damaging to motivation (Deci et al., 1999). These meta-analytic findings raise questions about current compensation practices in organizations 
and their potential effects on employee motivation. Real world compensation systems, however, cannot easily be categorized within these different types of contingencies. Therefore, we cannot easily extrapolate the metaanalytic results to the organizational field. Indeed, an attempt to replicate the Deci et al. (1999) results in a field study of the motivational effects of compensation was unsuccessful (Fang \& Gerhart, 2000). In fact, employees under a pay-for-performance system reported greater intrinsic job interest than employees under a base pay system. It seems possible that real-life compensation systems affect need satisfaction differently than laboratory reward systems because of differences in importance, size, and time frame (Rynes, Gerhart \& Parks, 2005). We propose that by unpacking the major dimensions of compensation systems, we can identify their effects on need satisfaction and motivation.

\section{Compensation Systems in Organizations}

Compensation is one of the principal components of a human resource system, and it is defined as the rewards (monetary and nonmonetary) that employees receive for performing their job (Martocchio, 2001). Monetary compensation includes base pay (which is fixed), pay adjustments (e.g., a market supplement), and incentive pay (which is variable). Nonmonetary rewards include fringe benefits, some of which are legally required (e.g., disability and unemployment insurance), and some of which are discretionary (e.g., income protection, wellness programmes, and employee assistance programmes). Examples of popular pay systems such as performance and merit pay are given in the Appendix. They are often used in combinations. Variable pay systems are currently very popular and are recommended by human resources specialists because such systems are thought to bring competitive advantage to the organization (e.g., Lawler, 2000). This assumption relies on the expectancy theory framework (Vroom, 1964), whereby motivation is determined by people's self-efficacy beliefs, their perceptions of instrumentality between behavior and outcome, and the value of this outcome for the worker. For instance, Lawler (2000) heavily emphasises the need to reward employees according to the value they bring to the organization. An organization that profits from an employee's performance should share its success with that employee. Since companies no longer offer secure employment, Lawler argues that compensation is, nowadays, the only way they can enlist the commitment of employees to the organization. Moreover, it is only fair to pay the best employee substantially more than the poorest performer. Lawler calls for an organizational structure that replaces bureaucratic controls by fostering employee engagement through using information, knowledge, decision-making power, and rewards contingent on business success. Employees who bring value to the organization are those who manage themselves, do more complicated tasks, coordinate their work with the work of others, provide suggestions for improvement, and innovate. These competencies, we argue, require that employees not only have the abilities and resources, but must be autonomously motivated to use them.

The dominant view of compensation relies almost exclusively on the assumptions of agency theory (Jensen \& Meckling, 1976). This may be because most of the research on the effects of compensation systems on firm performance has been done in accounting and finance (where agency theory dominates), with little regard to intervening variables, such as employee motivation and performance. An agency relationship is defined as a contract between a 
principal (the employer) and an agent (the employee). The goal of the employer is to align the employee's goals to the employer's goals, and assumes that the employer must pay the employee for behavior that brings the employer closer to goal attainment. Compensation is therefore a control mechanism by which the employer influences the employee's behavior in a way that will benefit the employer. Nevertheless, not all economic research supports agency theory. For example, some research indicates that employer's use of control over the employee sometimes leads to a reduction in the employee's performance (Falk \& Kosfeld, 2006).

From the perspective of self-determination theory, one major problem of agency theory is that it assumes that the employee could not possibly internalize the employer's goals. Therefore, the only way the employer can influence the employee's behavior is through coercive methods, such as linking the employee's pay to organizational performance. Consistent with our thinking, Frey and Osterloh (2005) argue that agency theory relies solely on the concept of extrinsic motivation, and that incentive pay does not, in fact, lead to the expected goal alignment between employer and employee. These economists show that the relative price effect hypothesized by agency theory, whereby increases in payment lead to increases in effort, is counteracted by a "crowding out" effect on intrinsic motivation. The crowding out effect is the same detrimental effect of rewards on intrinsic motivation found within selfdetermination theory (Frey, 1993). The crowding out effect is effectively subtracted from the relative price effect, resulting in reduced effort. To avoid the crowding out effect, Frey and Osterloh advocate the use of fixed pay systems (i.e., noncontingent) coupled with a governance structure that fosters need satisfaction. Although they say that it is difficult to forecast the strength of the crowding out effect, we argue that it can be predicted if we carefully analyze the effects of compensation systems on need satisfaction.

\section{Research on Compensation}

Before proposing ways to test the effects of compensation systems on need satisfaction and work motivation, we review current compensation research to determine its effects on employee and organizational outcomes. The compensation literature has generally reported positive incentive effects on employee performance (Gerhart \& Rynes, 2003), and economic studies report anywhere from 4\% to $9 \%$ increases in firm performance (Booth \& Frank, 1999; Lazear, 2000; Piekkola, 2005). Such increases seem to be accounted for by factors such as reduced costs, improved employee retention, increased sales growth, increased customer satisfaction, and safety improvements (Werner \& Ward, 2004). However, these positive effects may be caused by two very different mechanisms: (a) an incentive effect, acting on employee motivation, and (b) a sorting effect, acting on the attraction and retention of the best performing employees (Lazear, 1986; Rynes, Gerhart, \& Parks, 2005).

A close examination of these incentive effects reveals several limiting conditions. For example, in one meta-analysis, monetary incentives had a positive effect on performance quantity, but not on performance quality (Jenkins, Mitra, Gupta, \& Shaw, 1998). Another meta-analysis showed positive effects of incentives in manufacturing firms, but not in service firms (Stajkovic \& Luthans, 1997). A more recent meta-analysis of the effects of performance-contingent rewards on performance that included studies from economics and 
psychology (unlike the previous metaanalyses) found an overall positive effect $\left(d_{-} 0.23\right.$ ), but this effect was moderated by task type. For simple and boring tasks, the effect was $d_{-} 0.42$, while for complex or interesting tasks, the effect was $d_{-}-0.13$ (Weibel, Rost, \& Osterloh, 2007). SDT actually predicts positive reward effects for algorithmic tasks, which ask for a straightforward solution or rule application, but more negative effects for heuristic tasks, which require more cognitive flexibility (Gagne' \& Deci, 2005). In fact, most studies that have found a positive effect of contingent pay plans on performance have used algorithmic tasks (Bandiera, Barankay, \& Rasul, 2007; Cadsby, Song, \& Tapon, 2007; Locke, Feren, McCaleb, Shaw, \& Denny, 1980), while studies that have found no effect or a negative effect used heuristic tasks (e.g., Amabile et al., 1990).

The compensation literature also failed to address the effects of compensation systems on employee mental health. Because of its reliance on agency theory, compensation researchers have neglected motivation theories that focus on needs and instead adopted the assumption that individuals can substitute one need for another (without any consequences) when their satisfaction is impossible (Jensen \& Meckling, 1994). Given the high costs of mental health problems to organizations and the economy (Stephens \& Joubert, 2001), it is important to address this issue. Apart from having studied the impact of compensation systems on job satisfaction (Igalens \& Roussel, 1999), pay satisfaction (Williams, McDaniel, \& Nguyen, 2006), and performance (as mentioned earlier), no research has examined the impact of compensation systems on employees' optimal functioning.

SDT offers a rich set of propositions that can help understand the impact of compensation systems on well being. Numerous studies have shown that anything that decreases need satisfaction, including reward systems, is likely to decrease subjective well-being (Ryan \& Deci, 2000). The literature on financial wealth and subjective wellbeing has shown clear empirical evidence that once basic physiological needs are met, adding wealth does not contribute significantly to increased subjective well-being (Diener, Sandvik, Seidlitz, \& Diener, 1993; Grouzet et al., 2005; Kasser, Cohn, Kanner, \& Ryan, 2007; Kasser \& Ryan, 1993; Lee, Sheldon, \& Turban, 2003; Oishi, Diener, Lucas, \& Suh, 1999) Perhaps it is because this wealth adds nothing to psychological need satisfaction. Extensive research shows that extrinsic motivation/goals/values generally have a negative impact on wellbeing while intrinsic motivation/goals/values have a positive impact on well-being (Baard et al., 2004; Grouzet et al., 2005; Kasser et al., 2007; Kasser \& Ryan, 1993; Lee et al., 2003; Oishi et al., 1999). By examining the effects of compensation systems on need satisfaction and work motivation, we can ascertain why, when, and how rewards have an effect (either positive or negative) on employee performance and well-being.

\section{A Model of the Effects of Compensation on Work Motivation}

Missing from our knowledge about compensation systems is their effects on the satisfaction of psychological needs, the key to promoting autonomous work motivation, better performance, and employee well being. Therefore, we propose that future research should examine the effects of compensation systems on the needs for autonomy, competence, and relatedness. This will help explain why certain compensation systems are more efficient for promoting the autonomous motivation of employees. As mentioned previously, the effects of 
compensation systems on need satisfaction and worker motivation can be assessed if we can extract essential characteristics of compensation systems that can be empirically studied. We took the compensation systems depicted in the appendix and analyzed their essential characteristics to extract dimensions along which we can categorize them. The process resulted in five dimensions that can be empirically operationalized: (a) the absolute amount of pay in monetary value; (b) the perceived equity of the compensation, operationalized in terms of distributive justice; (c) the ratio of fixed amount of pay versus the amount of pay that varies according to a certain criterion, such as performance; (d) the objectivity of the performance appraisal that determines compensation; and (e) the number of people whose performance is used to determine one's compensation, in other words, whether it is a group or individual incentive. Using these characteristics, we propose a model whereby the satisfaction of the needs for autonomy, competence and relatedness through compensation systems influences autonomous work motivation. In turn, autonomous motivation influences employee performance and well-being (see Figure 1).

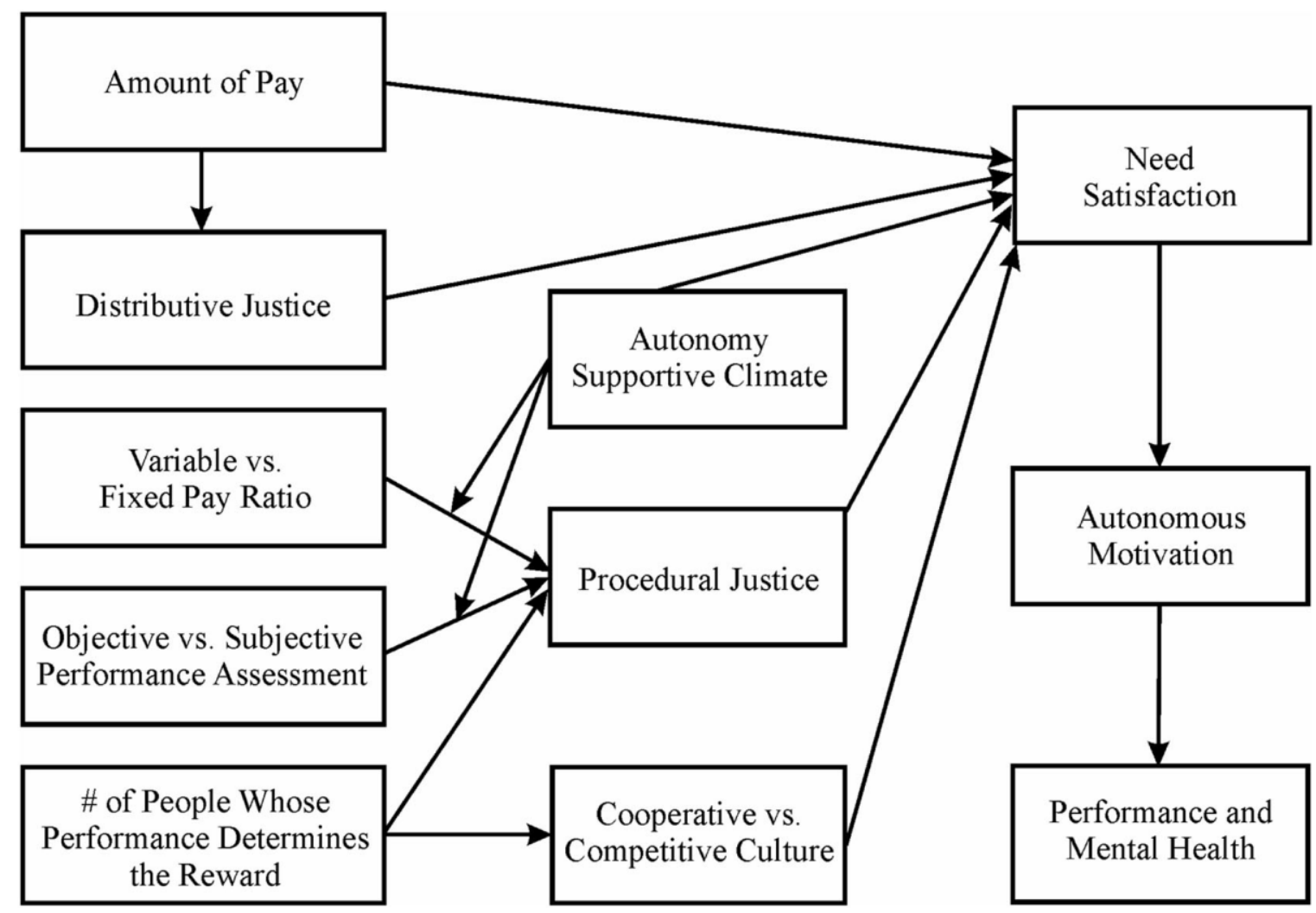

Figure 1. Model of compensation effects on work motivation.

We could use these dimensions to test total compensation packages or their components. For example, commission pay would lead to a certain amount of total pay that we can control for in analyzing the influence of this compensation system on employee motivation and performance. Perceptions of equity of this system can be assessed empirically with validated scales. The ratio of fixed versus variable pay can be assessed easily by determining if a commission is added to a fixed base salary. This ratio can be used as a variable in itself in the model. The performance measure that determines commissions will usually be a closed sales 
deal or an attained sales quota, which represents a relatively objective indicator. Finally, commissions are usually given based on individual performance. With this information, we can now predict the impact that commission pay will have on autonomous motivation. To do so, we added a few intervening variables to explain the impact of these compensation characteristics on employee motivation. Some mediators are proposed, namely, procedural justice and organizational culture. Work climate support is proposed as a moderator for some of the relations in the model (see Figure 1).

\section{Pay Level}

One study found that higher base pay fosters better performance and affective commitment, and that this can be explained through higher intrinsic work motivation (Kuvaas, 2006). The author contended that higher base pay signals the recognition of high competence and the valuation of the employer-employee relationship. The use of base pay that is above market average to attract good performers has also been advocated (Rynes, Gerhart, \& Minette, 2004). Therefore, we propose that high base pay or base pay that is above market average will foster greater need satisfaction, partly because of desirable social comparisons and improved perceptions of distributive justice (hence the link between amount of pay and distributive justice). Moreover, it is advisable to control for pay level when testing the effects of other compensation system characteristics.

\section{Ratio of Variable Versus Fixed Pay}

By assessing the ratio of variable versus fixed pay, we can determine the extent to which total pay is contingent on performance. A vignette study showed that a high proportion of performance-contingent pay was related to a larger decrement of intrinsic motivation, which in turn negatively affected performance (Weibel et al., 2007). High proportions of variable pay in the form of performance-contingent rewards have been positively related to turnover (Harrison, Virick, \& William, 1996). However, another study found a positive relation between bonus-to-base ratios (bonuses in the form of stock options) and organizational return on asset (Gerhart \& Milkovich, 1990). Therefore, more research is needed to determine the effects of these variable/fixed ratios on employee and organizational outcomes.

\section{Objectivity of the Performance Appraisal Methods}

Examining pay ratios is insufficient to understand all of the effects of compensation on need satisfaction. The way performance is assessed and used to determine rewards will also influence the impact of compensation systems on employee motivation. Whether compensation is based on one's individual characteristics (e.g., skill-based pay plan) or one's performance (e.g., commissions) will influence need satisfaction. Skill based pay plans are more likely to satisfy psychological needs, as they have been argued to improve the motivating potential of a job by providing workers with enriched jobs and opportunities to use more skills (Murray \& Gerhart, 1996). In contrast, commission-heavy pay systems breed more competition, which could diminish perceptions of relatedness and autonomy. The way performance appraisals are conducted also influences the impact of compensation systems on motivation. Merit pay systems are notorious for relying too much on subjective performance 
appraisals (i.e., managers' impressions), which makes employees dissatisfied because of negative procedural justice perceptions (Lawler, 2000; Pearce, Stevenson, \& Perry, 1985). Profit sharing relies on the output of a collective of individuals who will later share the fruit of their commonly created productivity. This is likely to foster greater relatedness, even if it could potentially decrease feelings of competence (because such systems are known to lack a clear link between individual performance and firm productivity; Magnan \& St-Onge, 2005). Two studies found that rewards in the form of profit sharing and stock ownership were positively related to affective organizational commitment (Coyle-Shapiro, Morrow, Richardson, \& Dunn, 2002; Kuvaas, 2003), which has been linked to autonomous motivation (Gagne', Boies, Martens, \& Donia, 2006).

\section{Individual Versus Group Incentives}

Some pay systems are individually based (e.g., commissions and merit increases), while others are group based (e.g., gain sharing). Group incentives have the propensity to increase the satisfaction of the need for relatedness relative to individual incentives. Group incentives can also foster a cooperative culture, while individual incentives run the risk of creating a competitive culture. However, as some economists have argued (Han \& Shen, 2007), group incentives can also lead to monitoring between employees, who will want to avoid free riding problems. This peer pressure can potentially decrease the satisfaction of the need for autonomy.

\section{Justice Perceptions}

Fairness is also an important predictor of autonomous work motivation. Distributive justice refers to the perceived fairness of decision outcomes relative to contributions (Adams, 1965; Leventhal, 1976). Procedural justice refers to the perceived fairness of processes used to arrive at outcome decisions (Byrne \& Cropanzano, 2001; Leventhal, 1980; Thibault \& Walker, 1975). A recent study found that both procedural and distributive justice perceptions were positively related to autonomous work motivation, and that need satisfaction completely mediated these effects (Gagne', Be'rube', \& Donia, 2007). Interestingly, one study found that contingent rewards are often perceived to be more fair, which increased the likelihood of need satisfaction, and ultimately, higher autonomous motivation (Gagne', 2008). This may explain the positive relations found between incentives and performance in some field studies (Fang \& Gerhart, 2000). It was also found that fairness can partly explain the positive effects of high base pay and stock ownership on performance and affective commitment (Kuvaas, 2003, 2006). Therefore, we propose distributive justice as an inherent characteristic of compensation systems, and hypothesize that it will directly influence need satisfaction (Gagne' et al., 2007). Procedural justice is influenced by other characteristics of the compensation system, namely, the ratio of variable versus fixed pay, the objectivity of the performance appraisal, and the number of people whose performance is used to determine a reward. 


\section{Organizational Culture}

Organizational culture is defined as a set of habitual ways of thinking, feeling, and behaving that are characteristic of members of an organization. Culture determines the norms that dictate how employees should think and behave (Kerr \& Slocum, 2005). Reward systems should reflect this culture, but will also reinforce it. Some research shows how easy it is to create norms, at least in experiments. For example, one study reported that simple instructions to cooperate increase cooperation by $40 \%$ (Frey \& Osterloh, 2005) and another found that task labelling (i.e., World Trade Center Game vs. Community Game) can influence cooperation versus competition tactics (Liberman, Samuels, \& Ross, 2004). Therefore, we can forecast that a culture that values cooperation over fostering individualism or competition will increase need satisfaction (especially relatedness).

Compensation specialists generally agree that compensation plans will affect the corporate culture (Baker, Jensen, \& Murphy, 1988). Commissions, for example, will foster individualistic, even egoistic and competitive, behavior. Profit sharing and gain sharing, in contrast, may foster more cooperation. Although many argue that culture and reward systems are inherently neither good nor bad, and that it all depends on their fit to the total organizational system (Kerr \& Slocum, 2005), SDT would argue that not all cultures and reward systems are good for individuals. Those systems that thwart need satisfaction will detract from employee engagement and well-being, which will ultimately cost the organization. Based on this, we hypothesize that the number of people whose performance determines one's reward will influence this aspect of organizational culture.

\section{Work Climate Support}

The general work climate, operationalized in terms of how supportive of psychological needs it is, will influence the interpretation of some compensation system characteristics. For the sake of simplicity, we define the general work climate through managerial support and job design. Goodman (2000) argued that incentives are related to business outcomes through "organizational linkages," like the manner in which incentives are used by managers, such that managerial styles may moderate the effects of incentives on work motivation and outcomes. Research has shown that jobs that are designed to be more meaningful and interesting increase autonomous motivation (Gagne', Se'ne'cal, \& Koestner, 1997). Research on transformational leadership shows that it has a positive impact on employee autonomous motivation (Bono \& Judge, 2003). Indeed, managers who support employees' psychological needs also have a positive impact on their autonomous motivation (Baard et al., 2004; Deci, Connell, \& Ryan, 1989; Deci, Ryan, \& Koestner, 2001). Therefore, we predict a direct relation between a supportive work climate and employee-need satisfaction. Adding this link allows one to study the relative impact of compensation on need satisfaction, and also possible interactions with other work climate factors. We expect that the work climate will influence whether the variable-to-fixed pay ratio will be interpreted as more or less controlling and informative about competence. Similarly, we expect that the work climate will influence how informative (and accurate) performance assessments are judged to be. These interactions will influence the extent to which these compensation characteristics will be judged as fair (as measured through procedural justice perceptions). Compensation systems 
that are least controlling and most informative should lead to greater need satisfaction (Ryan et al., 1983).

\section{Need Satisfaction}

Besides the already established research on the effects of need satisfaction on autonomous motivation (Deci \& Ryan, 1985), the compensation literature (e.g., Rynes, Gerhart, \& Minette, 2004; Rynes, Gerhart, \& Parks, 2005) correctly stresses that money has an impact on "lower-order needs" (such as shelter and food) and paves the way for "higher-order needs." This idea is based on older needs theories (Alderfer, 1972; Herzberg, 1966; Maslow, 1954) but is also compatible with SDT. The difference is that unlike other need theories, SDT has the tools to empirically test old theories. For example, it would now be possible to test Herzberg's (1996) hypothesis that pay is only a hygiene factor by testing the effects of compensation systems on need satisfaction and need frustration (Van den Broeck, Vansteenkiste, Lens, Soenens, \& DeWitte, 2007). Thus, we could test whether base pay diminishes autonomy and competence frustration, while profit sharing increases the feelings of autonomy and competence. SDT has also found some evidence for Alderfer's hypothesis that thwarting higher order needs leads to compensating by a focus on lower-order needs.

Thus, one study found that individuals who grew up in environments that did not support basic psychological needs later appeared to compensate for this deficit by overvaluing financial success (Kasser, Ryan, Zax, \& Sameroff, 1995).

\section{Conclusion}

The model we presented addresses Lawler's (2000) criticism that intrinsic motivation research has traditionally criticized the use of pay-for-performance without providing a clear alternative for organizations. It also answers Rynes et al.'s (2005) call for research on compensation that takes into account mediating psychological variables. Although SDT researchers have provided clear guidelines for engaging employees through leadership and job design, they have not yet addressed how to align reward systems with these other guidelines. We hope that empirical tests of this model will follow and result in clear guidelines on how to choose amongst different compensation systems, and even help develop new kinds of compensation systems that will foster and maintain autonomous motivation. 


\section{References}

Adams, J. S. (1963). Toward an understanding of inequity. Journal of Abnormal and Social Psychology, 67, 422-436.

Alderfer, C. P. (1972). Existence, relatedness, and growth. New York: Free Press.

Amabile, T. M., DeJong, W., \& Lepper, M. R. (1976). Effects of externally imposed deadlines on subsequent intrinsic motivation. Journal of Personality and Social Psychology, 34, 92-98.

Amabile, T. M., Goldfarb, P., \& Brackfield, S. C. (1990). Social influences on creativity: Evaluation, coaction, and surveillance. Creativity Research Journal, 3, 6-21.

Baard, P. P., Deci, E. L., \& Ryan, R. M. (2004). The relation of intrinsic need satisfaction to performance and well-being in two work settings. Journal of Applied Social Psychology, 34, 2045-2068.

Baker, G., Jensen, M. C., \& Murphy, K. J. (1988). Compensation and incentives: Practice vs. theory. Journal of Finance, 43, 593-616.

Bandiera, O., Barankay, I., \& Rasul, I. (2007). Incentives for managers and inequality among workers: Evidence from a firm-level experiment. Quarterly Journal of Economics, 122, 729773.

Bono, J. E., \& Judge, T. A. (2003). Self-concordance at work: Understanding the motivational effects of transformational leaders. Academy of Management Journal, 46, 554-571.

Booth, A. L., \& Frank, J. (1999). Earnings, productivity, and performance related pay. Journal of Labor Economics, 17, 447-462.

Byrne, Z. S., \& Cropanzano, R. (2001). The history of organizational justice: The founders speak. In R. Cropanzano (Ed.), Justice in the workplace: From theory to practice (Vol. 2, pp. 3-26). Mahwah, NJ: Erlbaum, Inc.

Cadsby, C. B., Song, F., \& Tapon, F. (2007). Sorting and incentive effects of pay for performance: An experimental investigation. Academy of Management Journal, 50, 387-405.

Coyle-Shapiro, J. A-M., Morrow, P. C., Richardson, R., \& Dunn, S. R. (2002). Using profit sharing to enhance employee attitudes: A longitudinal examination of the effects on trust and commitment. Human Resource Management, 41, 423-439.

Deci, E. L., Connell, J., \& Ryan, R. M. (1989). Self-determination in a work organization. Journal of Applied Psychology, 74, 580-590. 
Deci, E. L., Gagné, M., Ryan, R. M., Leone, D. L., Usunov, J., \& Kornazheva, B. P. (2001). Need satisfaction, motivation and well-being in the work organizations of a former eastern bloc country: A crosscultural study of self-determination. Personality and Social Psychology Bulletin, 27, 930-942.

Deci, E. L., Koestner, R., \& Ryan, R. M. (1999). A meta-analytic review of experiments examining the effects of extrinsic rewards on intrinsic motivation. Psychological Bulletin, 125, 627-668.

Deci, E. L., \& Ryan, R. M. (1985). Intrinsic motivation and self determination in human behavior. New York: Plenum Press.

Deci, E. L., \& Ryan, R. M. (2000). The 'what' and 'why' of goal pursuits: Human needs and the self-determination of behavior. Psychological Inquiry, 11, 227-268.

Deci, E. L., Ryan, R. M., \& Koestner, R. (2001). The pervasive negative effects of rewards in educational settings: A reply to Cameron. Review of Educational Research, 71, 43-52.

Diener, E., Sandvik, E., Seidlitz, L., \& Diener, M. (1993). The relationship between income and subjective well-being: Relative or absolute? Social Indicators Research, 28, 195-223.

Falk, A., \& Kosfeld, M. (2006). The hidden costs of control. American Economic Review, 96, 1611-1630.

Fang, M. Y., \& Gerhart, B. (2000). Does pay for performance diminish intrinsic interest? A workplace test using cognitive evaluation theory and the attraction-selection-attrition hypothesis. Unpublished manuscript, University of Wisconsin.

Frey, B. S. (1993). Motivation as a limit to pricing. Journal of Economic Psychology, 14, 635-664.

Frey, B. S., \& Osterloh, M. (2005). Yes, managers should be paid like bureaucrats. Journal of Management Inquiry, 14, 96-111.

Gagné, M. (2003). The role of autonomy support and autonomy orientation in the engagement of prosocial behavior. Motivation and Emotion, 27, 199-223.

Gagné, M. (2008). Relations between reward contingencies, procedural justice and work motivation. Paper presented at the Society for Industrial and Organizational Psychology, San Francisco.

Gagné, M., Be'rube', N., \& Donia, M. (2007). Relationships between different forms of organizational justice and different motivational orientations. Poster presented at the Society for Industrial and Organizational Psychology, New York. 
Gagné, M., Boies, K., Martens, M. L., \& Donia, M. (2006). A structural test of the relation between work motivation and organizational commitment. Paper presented at the Annual Meeting of the Administrative Sciences Association of Canada, Banff, AB.

Gagné, M., \& Deci, E. L. (2005). Self-determination theory and work motivation. Journal of Organizational Behavior, 26, 331-362.

Gagné, M., Se'ne'cal, C., \& Koestner, R. (1997). Proximal job characteristics, feelings of empowerment, and intrinsic motivation: A multidimensional model. Journal of Applied Social Psychology, 27, 1222-1240.

Gerhart, B., \& Milkovich, G. T. (1990). Organizational differences in managerial compensation and financial performance. Academy of Management Journal, 33, 663-691.

Gerhart, B., \& Rynes, S. L. (2003). Compensation: Theory, evidence, and strategic implications. Thousand Oaks, CA: Sage.

Goodman, P. S. (2000). Missing organizational linkages: Tools for crosslevel research. Thousand Oaks, CA: Sage.

Grouzet, F., Kasser, T., Ahuvia, A., Fernandez-Dols, J. M., Kim, Y., Lau, S., et al. (2005). The structure of goal contents across 15 cultures. Journal of Personality and Social Psychology, 89, 800-806.

Han, T. -S., \& Shen, C. -H. (2007). The effects of bonus systems on firm performance in Taiwan's high-tech sector. Journal of Comparative Economics, 35, 235-249.

Harrison, D. A., Virick, M., \& William, S. (1996). Working without a net: Time, performance, and turnover under maximally contingent rewards. Journal of Applied Psychology, 81, 331-345.

Herzberg, F. (1966). Work and the nature of man. Cleveland, OH: World. Igalens, J., \& Roussel, P. (1999). A study of the relationship between compensation package, work motivation and job satisfaction. Journal of Organizational Behavior, 20, 1003-1025.

Ilardi, B. C., Leone, D., Kasser, T., \& Ryan, R. M. (1993). Employee and supervisor ratings of motivation: Main effects and discrepancies associated with job satisfaction and adjustment in a factory setting. Journal of Applied Social Psychology, 23, 1789-1805.

Jenkins, G. B., Mitra, A., Gupta, N., \& Shaw, J. B. (1998). Are financial rewards related to performance? A meta-analytic review of empirical research. Journal of Applied Psychology, $83,777-787$.

Jensen, M. C., \& Meckling, W. H. (1976). Theory of the firm: Managerial behavior, agency costs, and ownership structure. Journal of Financial Economics, 3, 305-360. 
Jensen, M. C., \& Meckling, W. H. (1994). The nature of man. Journal of Applied Corporate Finance, 7, 4-19.

Kasser, T., Cohn, S., Kanner, A. D., \& Ryan, R. M. (2007). Some costs of American corporate capitalism: A psychological exploration of value and goal conflicts. Psychological Inquiry, 18, 1-22.

Kasser, T., \& Ryan, R. M. (1993). A dark side of the American dream: Correlates of financial success as a central life aspiration. Journal of Personality and Social Psychology, 65, 410422 .

Kasser, T., Ryan, R. M., Zax, M., \& Sameroff, A. J. (1995). The relations of maternal and social environments to late adolescents' materialistic and prosocial values. Developmental Psychology, 31, 907-914.

Kerr, J., \& Slocum, J. W. J. (2005). Managing corporate culture through reward systems. Academy of Management Executive, 19, 130-138.

Koestner, R., \& Losier, G. F. (2002). Distinguishing three ways of being internally motivated: A closer look at introjection, identification, and intrinsic motivation. In E. L. Deci \& R. M. Ryan (Eds.), Handbook of self-determination research (pp. 101-121). Rochester, NY: University of Rochester Press.

Koestner, R., Losier, G. F., Vallerand, R. J., \& Carducci, D. (1996). Identified and introjected forms of political internalization: Extending self-determination theory. Journal of Personality and Social Psychology, 70, 1025-1036.

Kuvaas, B. (2003). Employee ownership and affective organizational commitment: Employees' perceptions of fairness and their preference for company shares over cash. Scandinavian Journal of Management, 19, 193-212.

Kuvaas, B. (2006). Work performance, affective commitment, and work motivation: The roles of pay administration and pay level. Journal of Organizational Behavior, 27, 365-385.

Lawler, E. E. III. (2000). Rewarding excellence: Pay strategies for the new economy. San Francisco: Jossey-Bass.

Lazear, E. P. (1986). Salaries and piece rates. Journal of Business, 59, 405-431.

Lazear, E. P. (2000). Performance pay and productivity. American Economic Review, 90, $1346-1361$.

Lee, F. K., Sheldon, K. M., \& Turban, D. B. (2003). Personality and goal-striving process: The influence of achievement goal patterns, goal level, and mental focus on performance and enjoyment. Journal of Applied Psychology, 88, 256-265. 
Lepper, M. R., \& Greene, D. (1975). Turning play into work: Effects of adult surveillance and extrinsic rewards on children's intrinsic motivation. Journal of Personality and Social Psychology, 31, 479-486.

Leventhal, G. S. (1976). The distribution of rewards and resources in groups and organizations. In L. Berkowitz \& W. Walster (Eds.), Advances in experimental social psychology (Vol. 9, pp. 91-131). New York: Academic Press.

Leventhal, G. S. (1980). What should be done with equity theory? New approaches to the study of fairness in social relationships. In K. Gergen, M. Greenberg, \& R. Willis (Eds.), Social exchange: Advances in theory and research (pp. 27-55). New York: Plenum Press.

Liberman, V., Samuels, S. M., \& Ross, L. (2004). The name of the game: Predictive power of reputations versus situational labels in determining prisoner's dilemma game moves. Personality and Social Psychology Bulletin, 30, 1175-1185.

Locke, E. A., Feren, D. B., McCaleb, V. M., Shaw, K. N., \& Denny, A. T. (1980). The relative effectiveness of four methods of motivating employee performance. In K. Duncan, M. Grunenberg, \& D. Wallis (Eds.), Changes in working life. New York: Wiley.

Lynch, M. F., Jr., Plant, R., \& Ryan, R. M. (2005). Psychological needs and threat to safety: Implications for staff and patients in a psychiatric hospital for youth. Professional Psychology, 36, 415-425.

Magnan, M., \& St-Onge, S. (2005). The impact of profit sharing on the performance of financial services firms. Journal of Management Studies, 42, 761-791.

Martocchio, J. J. (2001). Strategic compensation: A human resource management approach (3rd ed.). Upper Saddle River, NJ: Pearson.

Maslow, A. H. (1954). Motivation and personality. New York: Harper \& Row.

Meyer, J. P., \& Gagne', M. (2008). Employee engagement from a selfdetermination theory perspective. Industrial and Organizational Psychology, 1, 60-62.

Millette, V., \& Gagne', M. (2008). Designing volunteers' tasks to maximize motivation, satisfaction and performance: The impact of job characteristics on the outcomes of volunteer involvement. Motivation and Emotion, 32, 11-22.

Murray, B., \& Gerhart, B. (1996). An empirical analysis of a skill-based pay program and plant performance outcomes. Academy of Management Journal, 41, 68-78.

Oishi, S., Diener, E. F., Lucas, R. E., \& Suh, E. M. (1999). Cross-cultural variations in predictors of life satisfaction: Perspectives from needs and values. Personality and Social Psychology Bulletin, 25, 980-990. 
Pearce, J. L., Stevenson, W. B., \& Perry, J. L. (1985). Managerial compensation based on organizational performance: A time series analysis of the effects of merit pay. Academy of Management Journal, 28, 261-278.

Piekkola, H. (2005). Performance-related pay and firm performance in Finland. International Journal of Manpower, 26, 619-635.

Ryan, R. M. (1995). Psychological needs and the facilitation of integrative processes. Journal of Personality, 63, 397-427.

Ryan, R. M., \& Deci, E. L. (2000). Self-determination theory and the facilitation of intrinsic motivation, social development, and well-being. American Psychologist, 55, 68-78.

Ryan, R. M., Mims, V., \& Koestner, R. (1983). Relation of reward contingency and interpersonal context to intrinsic motivation: A review and test using cognitive evaluation theory. Journal of Personality and Social Psychology, 45, 736-750.

Rynes, S. L., Gerhart, B., \& Minette, K. A. (2004). The importance of pay in employee motivation: Discrepancies between what people say and what they do. Human Resource Management, 43, 381-394.

Rynes, S. L., Gerhart, B., \& Parks, L. (2005). Personnel psychology: Performance evaluation and pay for performance. Annual Review of Psychology, 56, 571-600.

Sheldon, K. M., \& Elliot, A. J. (1998). Not all personal goals are "personal": Comparing autonomous and controlling goals on effort and attainment. Personality and Social Psychology Bulletin, 24, 546-557.

Smith, W. E. (1975). The effect of anticipated vs. unanticipated social reward on subsequent intrinsic motivation. Unpublished dissertation, Cornell University. Stajkovic, A. D., \& Luthans, F. (1997). A meta-analysis of the effects of organizational behavior modification on task performance, 1975-1995. Academy of Management Journal, 40, 1122-1149.

Stephens, T., \& Joubert, N. (2001). The economic burden of mental health problems in Canada. Chronic diseases in Canada, 22, 18-23.

Thibault, J., \& Walker, L. (1975). Procedural justice: A psychological analysis. Hillsdale, NJ: Erlbaum.

Vallerand, R. J. (1997). Toward a hierarchical model of intrinsic and extrinsic motivation. In M. P. Zanna (Ed.), Advances in experimental social psychology, 29 (pp. 271-360). San Diego: Academic Press.

Van den Broeck, A., Vansteenkiste, M., Lens, W., Soenens, B., \& DeWitte, H. (2007). Development of a new need satisfaction at work scale: Examining the independent effects of 
autonomy, competence, and relatedness on job well-being and performance. Poster presented at the Third International Conference on Self-Determination Theory, Toronto, ON.

Vroom, V. H. (1964). Work and motivation. New York: Wiley.

Weibel, A., Rost, K., \& Osterloh, M. (2007). Crowding-out of intrinsic motivation: Opening the black box. Unpublished manuscript, IOU Institute for Organizational and Administrative Science, University of Zurich.

Werner, S., \& Ward, S. G. (2004). Recent compensation research: An eclectic review. Human Resource Management Review, 14, 201-227.

Williams, M. L., McDaniel, M. A., \& Nguyen, N. T. (2006). A metaanalysis of the antecedents and consequences of pay level satisfaction. 


\section{Appendix 1}

\section{Popular Compensation Plans}

\begin{tabular}{|c|c|c|}
\hline Compensation system & $\begin{array}{l}\text { Reward determined } \\
\text { by performance of }\end{array}$ & Description \\
\hline Base pay & Individual & $\begin{array}{l}\text { Giving a fixed amount of pay on a regular basis (e.g., hourly, } \\
\text { weekly, monthly) for occupying a position in the } \\
\text { organization, regardless of performance. Amount is most } \\
\text { often determined by job type, seniority, or rank. }\end{array}$ \\
\hline Pay-for-performance & Individual & $\begin{array}{l}\text { Giving a set monetary reward for a pre-defined performance } \\
\text { unit (e.g., commissions, piece-rate). }\end{array}$ \\
\hline Bonus & Individual & $\begin{array}{l}\text { Giving a set monetary reward for attaining a certain perfor- } \\
\text { mance standard or quota. }\end{array}$ \\
\hline Merit pay & Individual & Increasing base pay based on yearly performance appraisal. \\
\hline Skill based pay & Individual & $\begin{array}{l}\text { Increasing base pay based on skill or knowledge } \\
\text { competencies and acquisition. }\end{array}$ \\
\hline Gainsharing & Group & $\begin{array}{l}\text { Giving a monetary reward (equality or equity based } \\
\text { distribution to individuals) based on reaching a group - } \\
\text { based goal or quota (e.g., reducing scraps) }\end{array}$ \\
\hline Profit sharing & Organizational & $\begin{array}{l}\text { Sharing the organization's profit with its employees. Pay out } \\
\text { is based on a profitability target. }\end{array}$ \\
\hline Stocks and options & Organizational & $\begin{array}{l}\text { Giving stock ownership or the right to purchase a fixed } \\
\text { number of shares of stock at a fixed price, regardless of } \\
\text { actual stock price. }\end{array}$ \\
\hline
\end{tabular}

